\title{
Apoptotic Changes in the Early Diagnosis and Severity Determination of Neonatal Sepsis
}

\author{
Naglaa Fathy Barseem, ${ }^{1,}$ and Mohamed Ahmed Helwa ${ }^{2}$ \\ ${ }^{1}$ Pediatric Department, Faculty of Medicine, Menoufia University, Egypt \\ ${ }^{2}$ Clinical Pathology Department, Faculty of Medicine, Menoufia University, Egypt \\ "Corresponding author: Naglaa Fathy Barseem, Pediatric Department, Faculty of Medicine, Menoufia University, Egypt. Tel: +20-1000314897, E-mail: naglaa_b2000@yahoo.com
}

Received 2016 June 28; Revised 2016 July 31; Accepted 2016 August 23.

\begin{abstract}
Objectives: The aim of this study was to assess the presence of DNA damage in full-term newborns with neonatal sepsis.

Methods: Sixty neonates with early onset neonatal sepsis and 45 apparently healthy controls were enrolled in the study. Screening of neonates was done using a modified clinical sepsis score and hematological scoring system, adjusted to the results of blood culture and screening tests. Complete blood count, C-reactive protein (CRP), and DNA studies were done.

Results: Sepsis was likely in 41 (68.3\%) patients with scores of 3 or 4 and CRP levels of $12-48 \mathrm{mg} / \mathrm{L}$. Sepsis was very likely in 19 (31.7\%) patients with scores of $\geq 5$ and CRP of $48-96 \mathrm{mg} / \mathrm{L}$. Sepsis was unlikely in all controls with scores of $\leq 2$. The mean neutrophil count was $9700 \pm 4600 / \mu \mathrm{L}$ in patients and $4230 \pm 1400 / \mu \mathrm{L}$ in controls. The higher the total polymorphonuclear count and CRP level, the more severe was the sepsis. Twenty-six of $60(43.3 \%)$ sepsis patients and 5 of 45 controls (11\%) had DNA damage. There was a highly significant negative correlation between DNA damage, blood culture results, and CRP levels.

Conclusions: DNA damage, demonstrated by clinical and laboratory evidence with a combination of blood cultures, CRP, and hematological scoring system results, can be used as an indicator of both the immune status of the neonate and the severity of the sepsis.
\end{abstract}

Keywords: Apoptosis, Neonatal sepsis, Newborn, Sepsis

\section{Background}

Neonatal sepsis is a clinical syndrome of bacteremia characterized by systemic signs, which may be categorized as early-onset sepsis with acquisition by microorganisms of maternal origin, most commonly associated with Group B streptococci, Escherichia coli, coagulase-negative staphylococci, Haemophilus influenzae, and Listeria monocytogenes. Late-onset sepsis occurs at 4 - 90 days of life and is acquired from the caregiving environment (1). Polymerase chain reaction (PCR) can be used to identify sepsis and the causative organism more quickly than blood cultures alone (2). The hematological scoring system (HSS) can be used either singly or in combinations as an early indicator for a diagnosis of neonatal sepsis (3). CRP levels usually begin to rise within 4-6 hours of the onset of sepsis, with peak levels reached within 48 - 72 hours and remaining elevated until resolution of the inflammatory process (4).

Neutrophils are the most abundant cells of the innate immune system. When neutrophils are stimulated by microorganisms, they become activated and increase their oxidative metabolism and unorganized release of toxic derivatives that affect many macromolecules, including proteins, carbohydrates, lipids, and nucleic acids. This results in cell injury and may induce cell death and apoptosis (5). Once the physiological functions of neutrophils have been fulfilled in the tissues, they undergo spontaneous apoptosis to preserve neutrophil membrane integrity in equilibrium with free-radical generation and antioxidant defenses (6). The resolution of inflammation therefore relies on the effective switching-off mechanism of neutrophils, the promotion of apoptosis, and the successful clearance of these cells (7). Great interest in this research area is directed toward targeting apoptosis by treating neutrophil-dominant inflammatory diseases in a timely and controlled manner $(8,9)$.

\section{Objectives}

The present study was conducted to assess DNA damage in newborns with neonatal septicemia.

\section{Methods}

This study was conducted on 60 full-term neonates (40 males and 20 females) with early onset sepsis (EOS), with a mean age of $2.9 \pm 1.3$ days (Group I). The infants had all been admitted to the neonatal care unit at Menoufia university children's hospital. Forty-five age- and gendermatched apparently healthy neonates were used as controls ( 25 males and 20 females with a mean age of $2.8 \pm 1.4$ days), who were admitted to the nursery for observation due to mild respiratory distress during the first few days of life, with no clinical or laboratory evidence of sepsis. 
Written informed consent was obtained from the patient's guardians, and the study was conducted from June 2014 to January 2016. Ethical approval was obtained from the institutional ethics committee. Our protocol conformed to the ethical guidelines of the 1964 Declaration of Helsinki and its later amendments.

The neonates were screened for sepsis using the modified clinical sepsis score (10) and hematological sepsis score (3). Term neonates who were diagnosed clinically and fulfilled at least two septic screening tests were enrolled in the study group. The septic screening involved increased $\mu$-erythrocyte sedimentation rate ( $\mu \mathrm{ESR})$, C-reactive protein (CRP), and band-cell count (11). Sepsis was confirmed when blood cultures and septic screenings were positive. To determine the severity of neonatal sepsis, the diagnosis was based on the most recent world health organization multisite study of severe illness in young infants, including the presence of any of the clinical signs and symptoms indicating organ dysfunction, (history of difficult feeding, history of convulsions, movement only when stimulated, respiratory rate of $\geq 60$ breaths $/ \mathrm{min}$, severe chest in-drawing, temperature of $\geq 37.5^{\circ} \mathrm{C}$ or $\leq$ $35.5^{\circ} \mathrm{C}$ ), along with evidence of blood perfusion abnormalities and predicted required hospitalizations for 0 - 7 days in ill neonates (12). Patients with indirect or direct hyperbilirubinemia, prenatal asphyxia, prematurity, postmaturity, and congenital malformations were excluded.

All neonates in this study underwent detailed historytaking with an emphasis on maternal obstetric history, premature or prolonged rupture of membranes, maternal fever, maternal medications or a history of chronic illness before or during pregnancy, and mode of delivery. Thorough general and local-system clinical examinations were performed, including cardiovascular, chest, neurological, abdominal, and skin evaluations. The laboratory investigations included a complete blood count (total and differential), $\mu$ ESR by spectrometric analysis, and CRP using the latex agglutination method (13). As an initial step in the sepsis workup, blood was drawn into blood culture bottles (Egyptian Diagnostic Media) before initiation of antibiotic therapy and under aseptic techniques according to standard microbiological methods (14). Gramstaining and observation under high-power field light microscopy was performed to diagnose sepsis according to the HSS (3), which included total leucocyte count, total polymorphonuclear (PMN) count, immature PMN count, immature/total PMN ratio, degenerative PMN changes, and platelet count.

To detect DNA damage, blood samples were collected from a peripheral vein into heparinized tubes within 24 hours of the diagnosis of sepsis and prior to initiation of antibiotic therapy. The samples were processed immedi- ately to avoid further DNA damage. DNA damage was estimated following DNA extraction using Gene Jet Whole Blood Genomic DNA Purification Mini Kits, then visualized by gel electrophoresis (15).

\subsection{Statistical Analysis}

Data were analyzed using SPSS version 12 for Windows. Qualitative data are presented as numbers and percentages, whereas quantitative data are presented as mean \pm standard deviation with ranges. Student's t-test was used to test differences in means, while the Mann-Whitney Utest was used for non-parametric statistics. Pearson's correlation coefficient was used to test the correlation of various variables within the case group. P-values of $<0.05$ were considered to show statistical significance.

\section{Results}

Regarding the demographic data of the studied neonates, the mean age of the patients was $2.9 \pm 1.3$ days, which was not significantly different from that of the controls ( $2.8 \pm 1.4$ days, $\mathrm{P}>0.05)$. The percentage of males was $66.7 \%$ in the patient group and $56.7 \%$ in the control group. The neonatal sepsis group had significantly lower Apgar scores, with scores of $8-10$ in $76.6 \%$ and $4-7$ in $23.3 \%$ of cases, compared to $100 \%$ of the control group having scores of $8-10(\mathrm{P}<0.05)$. These lower Apgar scores were positively correlated with inhibited neutrophilic apoptosis $(\mathrm{r}=0.42)$. There was no significant difference in the mode of delivery between the patients and controls. The percentage of culture-positive cases in this study was $72.3 \%(n=43)$.

Laboratory investigations showed that total leukocyte count, total PMN, immature PMN count, platelet count, and CRP levels were of statistical significance in a comparison between patients and controls (Table1). There were significant differences between culture-positive and culturenegative cases with regard to WBC count, hemoglobin level, and immature neutrophils, but no statistically significant differences were found in the other parameters (Table 2). TLC, immature PMN count, and immature/mature PMN ratios showed statistically significant differences between patients with DNA damage and those without DNA damage. Meanwhile, total PMN count, immature/total PMN ratio, and platelet count showed no significant differences.

In our study, sepsis was likely in 41 (68.3\%) patients with a score of 3 or 4 and a CRP of 12 - $48 \mathrm{mg} / \mathrm{L}$, while sepsis was very likely in $19(31.7 \%)$ patients classified as having no DNA damage, a score of $\geq 5$, and CRP of 48 - $96 \mathrm{mg} / \mathrm{L}$. Sepsis was 
Table 1. Laboratory Data of Studied Groups ${ }^{\mathrm{a}}$

\begin{tabular}{|c|c|c|c|c|c|}
\hline Parameter & Patients & Controls & Test & Value & P-Value \\
\hline TLC, $\times 10^{3} / \mu \mathrm{L}$ & $17.5 \pm 5.4$ & $7.9 \pm 2.8$ & T-test & 8.07 & $<0.001$ \\
\hline Total PMN count, $\times 10^{3} / \mu \mathrm{L}$ & $9.7 \pm 4.6$ & $4.23 \pm 1.4$ & Mann-Whitney U-test & 89.0 & $<0.001$ \\
\hline Immature PMN count, $\times 10^{3} \mid \mu \mathrm{L}$ & $2.8 \pm 2.2$ & $0.7 \pm 0.1$ & Mann-Whitney U-test & 96 & $<0.001$ \\
\hline Immature/total PMN ratio & $0.31 \pm 0.22$ & $0.14 \pm 0.01$ & Mann-Whitney U-test & 213 & $<0.001$ \\
\hline Immature/mature PMN ratio & $0.88 \pm 1.17$ & $0.17 \pm 0.08$ & Mann-Whitney U-test & 219.5 & $<0.001$ \\
\hline Platelet count, $\times 10^{3} / \mu \mathbf{L}$ & $149.6 \pm 82$ & $228.3 \pm 36.2$ & Mann-Whitney U-test & 124.5 & $<0.001$ \\
\hline C-reactive protein, $\mathrm{mg} / \mathrm{L}$ & $13.6 \pm 4.9$ & $4.1 \pm 1.4$ & Mann-Whitney U-test & 81 & $<0.001$ \\
\hline
\end{tabular}

Abbreviations: TLC, total leukocyte count; PMN, polymorphonuclear.

${ }^{\mathrm{a}}$ Values are expressed as mean $\pm \mathrm{SD}$.

Table 2. Hematological Findings in Relationship to Blood Culture Results Among Patients With Neonatal Sepsis

\begin{tabular}{|c|c|c|c|c|}
\hline \multirow[t]{2}{*}{ Mean \pm SD } & \multicolumn{2}{|c|}{ Blood Culture } & \multirow[t]{2}{*}{ Test $^{\mathbf{a}}$} & \multirow[t]{2}{*}{ P-Value } \\
\hline & + & - & & \\
\hline Hemoglobin, $\mathrm{g} / \mathrm{dL}$ & $13.71 \pm 1.82$ & $12.52 \pm 2.9$ & 1.48 & 0.014 \\
\hline TLC, $\times 10^{3}$ & $16.99 \pm 7.58$ & $8.45 \pm 6.02$ & 2.89 & 0.004 \\
\hline Immature PMN count, $\times 10^{3}$ & $2.34 \pm 1.09$ & $1.48 \pm 0.77$ & 2.26 & 0.024 \\
\hline Immature/total PMN ratio & $0.23 \pm 0.14$ & $0.18 \pm 0.07$ & 1.19 & 0.23 \\
\hline Platelet count, $\times 10^{3}$ & $195.72 \pm 84.67$ & $161.65 \pm 88.34$ & 0.91 & 0.35 \\
\hline
\end{tabular}

${ }^{\mathrm{a}}$ Mann-Whitney U-test.

unlikely in all of the controls, who had scores of $\leq 2$ according to the HSS (Table 3). On the other hand, by considering blood cultures as the gold standard for diagnosing infected neonates, a highly significant negative correlation ( $\mathrm{r}=-0.708, \mathrm{P}=0.001$ ) was found between culture-positive cases and those without DNA damage, with 29 patients representing $67.4 \%$ of culture-proven sepsis cases. In terms of DNA changes, 26 (43.3\%) patients and $5(11 \%)$ of the controls had DNA damage, in contrast to 34 (56.7\%) patients with no damage. DNA damage was in the form of hazy fragmented DNA as detected by gel electrophoresis (Figure 1). There was a highly significant negative correlation between DNA damage and CRP levels $(\mathrm{r}=0.804, \mathrm{P}<0.001)$. DNA damage was more common in neonates with lower hematological scores and CRP levels (Table 4). Similar findings were observed when analyzing the relationship between DNA damage and blood culture results; inhibited neutrophilic apoptosis was correlated with the severity of neonatal sepsis and blood culture positivity (Table 5).

\section{Discussion}

Neonatal sepsis is a major cause of morbidity and mortality during the first 28 days of life, contributing to $13 \%$ $15 \%$ of all neonatal deaths (16). Our study showed a higher prevalence (66.7\%) of neonatal sepsis among males compared to females. This was in accordance with Stoll in

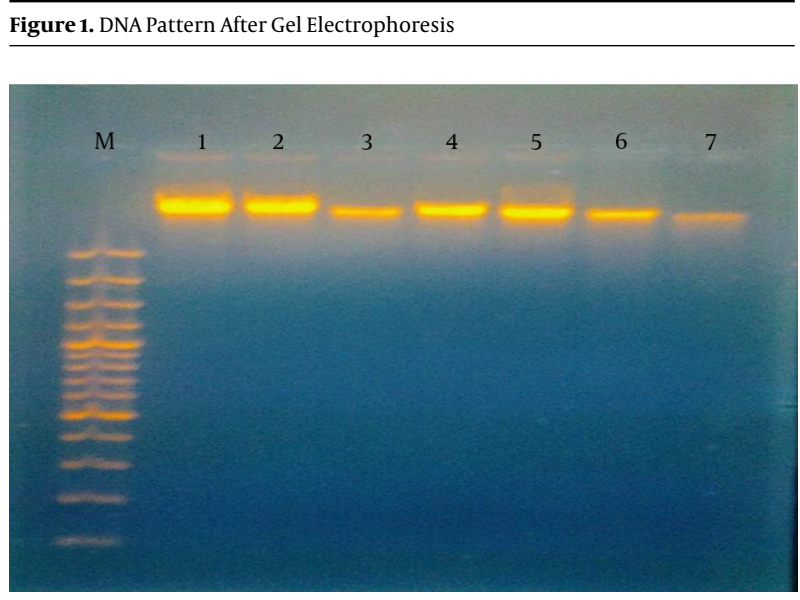

M, 100 bp DNA ladder, lanes 1, 2, 4, and 5 show normal DNA patterns; lanes 3, 6, and 7 show hazy fragmented DNA.

2008 (17), who found that males have an approximately two-fold higher incidence of sepsis than females, suggesting the possibility of a sex-linked factor in host susceptibility. There was no difference between our patients and the controls with regard to parity, mother's age, and mode of delivery. In contrast to the results of our study, Hornik et al. (18) showed that babies born by vaginal delivery are more likely to have early onset sepsis than those 
Table 3. Relationship Between DNA Damage and HSS in Patients ${ }^{\mathrm{a}}$

\begin{tabular}{|c|c|c|c|c|}
\hline \multirow[t]{2}{*}{ Scoring System } & \multicolumn{2}{|c|}{ Patients $(n=60)$} & \multirow[t]{2}{*}{$\mathrm{X}^{2}$} & \multirow[t]{2}{*}{ P-Value } \\
\hline & DNA damage, $(n=26)$ & No DNA damage, $(n=34)$ & & \\
\hline $\operatorname{TLC}\left(\times 10^{3}\right)$ & & & 1.35 & $>0.05$ \\
\hline Score $(0)$ & $20(76.9)$ & $21(61.7)$ & & \\
\hline Score (1) & $6(23.1)$ & $13(38.2)$ & & \\
\hline Total PMN count, $\times 10^{3}$ & & & 1.26 & $>0.05$ \\
\hline Score $(0)$ & $9(34.6)$ & $5(14.7)$ & & \\
\hline Score (1) & $17(65.4)$ & $29(85.3)$ & & \\
\hline Immature PMN count $\left(\times 10^{3}\right)$ & & & 8.0 & $<0.05$ \\
\hline Score $(0)$ & $7(27)$ & $0(0)$ & & \\
\hline Score (1) & $19(73)$ & $34(100)$ & & \\
\hline Immature/total PMN ratio & & & 4.15 & $<0.05$ \\
\hline Score $(0)$ & $11(42.3)$ & $4(11.7)$ & & \\
\hline Score (1) & $15(57.7)$ & $30(88.3)$ & & \\
\hline Immature/mature PMN ratio & & & 4.513 & $<0.05$ \\
\hline Score $(0)$ & $17(65.4)$ & $5(14.7)$ & & \\
\hline Score (1) & $9(34.6)$ & $29(85.3)$ & & \\
\hline Degenerative changes & & & 3.17 & $>0.05$ \\
\hline Score (0): none & $20(77)$ & $14(41)$ & & \\
\hline Score (1): toxic granules or cytoplasmic vacuoles & $6(33)$ & $20(59)$ & & \\
\hline Platelet count, $\times 10^{3}$ & & & 0.62 & $>0.05$ \\
\hline Score $(0)$ & $15(57.7)$ & $18(53)$ & & \\
\hline Score (1) & $11(42.3)$ & $16(47)$ & & \\
\hline
\end{tabular}

${ }^{\mathrm{a}}$ Values are expressed as No. (\%).

Table 4. Relationship Between Severity of Sepsis and DNA Damage in Sepsis Patients ${ }^{\mathrm{a}}$

\begin{tabular}{|c|c|c|c|c|c|}
\hline \multirow[t]{2}{*}{ Sepsis Degree } & \multirow[t]{2}{*}{ HSS } & \multirow[t]{2}{*}{ CRP, mg|L } & \multicolumn{2}{|c|}{ Patients $(n=60)$} & \multirow[t]{2}{*}{ Total, $(\mathbf{n}=60)$} \\
\hline & & & DNA damage, $(n=26)$ & No DNA damage, $(n=34)$ & \\
\hline \multirow{3}{*}{ Mild } & \multirow{3}{*}{ Sepsis likely likely (score 3 or 4 ) } & 12 & $21(80.7)$ & $2(5.9)$ & $23(38.3)$ \\
\hline & & 24 & $5(19.3)$ & $2(5.9)$ & $7(11.7)$ \\
\hline & & 48 & $0(0)$ & $11(32.3)$ & $11(18.3)$ \\
\hline \multirow{2}{*}{ Severe } & \multirow{2}{*}{ Sepsis very likely (score $\geq 5$ ) } & 54 & $0(0)$ & $7(20.6)$ & $7(11.7)$ \\
\hline & & 96 & $0(0)$ & $12(35.3)$ & $12(20)$ \\
\hline
\end{tabular}

Abbreviations: HSS, hematological scoring system; CRP, C-reactive protein

${ }^{\mathrm{a}}$ Values are expressed as No. (\%)

Table 5. Relationship Between Blood Culture Results and DNA Damage in Patients With Neonatal Sepsis

\begin{tabular}{|c|c|c|c|c|}
\hline Blood Culture & Sepsis Degree & CRP, mg/dL & DNA Damage $(n=26)$ & No DNA Damage $(n=34)$ \\
\hline \multirow{2}{*}{ Culture-unproven negative } & \multirow{2}{*}{ Mild } & 12 & $8(30.9)$ & $2(5.9)$ \\
\hline & & 24 & $5(19.2)$ & $2(5.9)$ \\
\hline \multirow{3}{*}{ Culture-proven positive } & Mild & 48 & $5(19.2)$ & $1(2.9)$ \\
\hline & \multirow{2}{*}{ Severe } & 54 & $5(19.2)$ & $13(38.2)$ \\
\hline & & 96 & $3(11.5)$ & $16(42.1)$ \\
\hline
\end{tabular}

${ }^{\mathrm{a}}$ Values are expressed as No. (\%).

delivered by cesarean section. Significantly lower Apgar scores were found in our patients compared to the con- trols. In agreement with our study, Strunk et al. (19) revealed that a low Apgar score at one minute might be at- 
tributed to neonatal sepsis, especially in the presence of risk factors for infection. The diagnosis of neonatal sepsis is a particular challenge; however, blood cultures remain the cornerstone for its evaluation; this was evident in our study, which revealed that sepsis severity was correlated with blood culture positivity among non-damaged DNA patients. This was in accordance with El Kebir and Janos (20), who showed that suppressed neutrophil apoptosis has been detected in patients with inflammatory diseases, such as acute respiratory distress syndrome, pneumonia, and sepsis. A frequent finding in these studies is the correlation of neutrophil apoptosis with the severity and/or outcome of the disease. The mean platelet count was significantly lower in the sepsis patients in the present study. Guida et al. (21) revealed that thrombocytopenia in neonatal sepsis is a combination of diffuse endothelial cell injury, bacterial/fungal toxins, increased platelet activation, and disseminated intravascular coagulation, resulting in increased platelet consumption and inadequately increased platelet production during sepsis.

In terms of DNA changes in our study, DNA damage was reported in $26(43.3 \%)$ patients and $5(11 \%)$ controls. Priyadharshini et al. (22) stated that inflammatory mediators released in response to toxins cause free-radical injury, which is explicated as DNA damage and can predict the severity and clinical outcome of neonatal sepsis. Carvalho et al. (23) reported DNA damage in neonatal sepsis as measured by the comet assay, and studied the diagnostic value of this assay in neonatal sepsis. In accordance with our study, Delanghe and Speeckaert (24) showed that antiapoptotic factors inhibit apoptosis during sepsis through intrinsic and extrinsic signaling pathways. This mechanism is involved in delayed neutrophil apoptosis. Meem et al. (25) also showed that pro-inflammatory cytokines, secreted after contact of neutrophils with lipopolysaccharides (LPS) in the cell membranes of invading microorganisms, strongly contribute to the inhibition of neutrophil apoptosis. Garcia et al. (26) revealed that delayed neutrophilic apoptosis and inadequate resolution of inflammation play a critical role in severe septic conditions, as well as in immune complex-mediated diseases. In this study, there was DNA damage in five $(11 \%)$ of the controls, which may be explained by the fact that some had mild respiratory distress with no evidence of sepsis. Yang et al. (27) observed that spontaneous in vitro granulocyte apoptosis at 6 hours, as reflected by phosphatidyl serine expression on the cell surface, was higher in granulocytes from human umbilical cord blood than in those from adult blood, and that DNA fragmentation, which is a late apoptotic marker, occurs by induction of granulocyte apoptosis. Scheel-Toellner et al. (28) found that neutrophils die even in the absence of any extrinsic factors, which is known as spontaneous death. Regimens such as the use of antioxidants may be useful in controlling septic granulocytopenia (29).

The results of our study revealed that there were negative correlations between the sum of the HSS, blood culture results, and CRP levels with regard to DNA damage in neonatal sepsis patients. Paunel-Gorgulu et al. (30) showed that the severity of sepsis correlated with reduced neutrophil apoptosis further supports the importance of neutrophil activity in the pathophysiology of sepsis, and drugs designed to target apoptotic signaling in neutrophils during sepsis may help to modulate the lifespan of neutrophils, thus preventing host tissue damage under these conditions. Furthermore, patients with septic shock who receive donor granulocytes show improvements in various biomarkers of sepsis, as well as decreased sepsis severity $(31,32)$.

\subsection{Conclusion}

CRP and morphological and degenerative changes in neutrophils are used not only for the early detection of neonatal sepsis but also to determine its degree of severity, which is shown on the basis of blood cultures. DNA damage and apoptotic changes in neutrophils can reflect the patient's immune status and help in the assessment of the severity of neonatal sepsis.

\section{Footnotes}

Authors' Contribution: Naglaa Fathy Barseem, conception and design of the study, data collection and analysis, participation in key technical aspects, writing of the draft, and final revision of the manuscript; Mohamed Ahmed Helwa, participation in conception and design of the study, participation in data analysis, participation in key technical aspects, and writing the draft of the manuscript.

Financial Disclosure: None to be declared.

\section{References}

1. van den Hoogen A, Gerards LJ, Verboon-Maciolek MA, Fleer A, Krediet TG. Long-term trends in the epidemiology of neonatal sepsis and antibiotic susceptibility of causative agents. Neonatology. 2010;97(1):228. doi: 10.1159/000226604. [PubMed: 19571584].

2. Chan KY, Lam HS, Cheung HM, Chan AK, Li K, Fok TF, et al. Rapid identification and differentiation of Gram-negative and Gram-positive bacterial bloodstream infections by quantitative polymerase chain reaction in preterm infants. Crit Care Med. 2009;37(8):2441-7. doi: 10.1097/CCM.ob013e3181a554de. [PubMed: 19531943].

3. Narasimha A, Harendra Kumar ML. Significance of Hematological Scoring System (HSS) in Early Diagnosis of Neonatal Sepsis. Indian J Hematol Blood Transfus. 2011;27(1):14-7. doi:10.1007/s12288-010-0050-2. [PubMed: 22379289]. 
4. Hawk M. C-reactive protein in neonatal sepsis. Neonatal Netw. 2008;27(2):117-20. doi: 10.1891/0730-0832.27.2.117. [PubMed: 18431965].

5. Serhan CN. Resolution phase of inflammation: novel endogenous anti-inflammatory and proresolving lipid mediators and pathways. Annu Rev Immunol. 2007;25:101-37. doi: 10.1146/annurev.immunol.25.022106.141647. [PubMed: 17090225].

6. Leitch AE, Duffin R, Haslett C, Rossi AG. Relevance of granulocyte apoptosis to resolution of inflammation at the respiratory mucosa. $\mathrm{Mu}$ cosal Immunol. 2008;1(5):350-63. doi: 10.1038/mi.2008.31. [PubMed: 19079199].

7. Martin C, Burdon PC, Bridger G, Gutierrez-Ramos JC, Williams TJ, Rankin SM. Chemokines acting via CXCR2 and CXCR4 control the release of neutrophils from the bone marrow and their return following senescence. Immunity. 2003;19(4):583-93. [PubMed: 14563322].

8. Serhan CN, Brain SD, Buckley CD, Gilroy DW, Haslett C, O'Neill LA, et al. Resolution of inflammation: state of the art, definitions and terms. FASEB J. 2007;21(2):325-32. doi: 10.1096/fj.06-7227rev. [PubMed: 17267386].

9. Sankar MJ, Agarwal R, Deorari AK, Paul VK. Sepsis in the newborn. Indian J Pediatr. 2008;75(3):261-6. [PubMed: 18376095].

10. Tollner U. Early diagnosis of septicemia in the newborn. Clinical studies and sepsis score. Eur J Pediatr. 1982;138(4):331-7. [PubMed: 7128642].

11. Singh NP, McCoy MT, Tice RR, Schneider EL. A simple technique for quantitation of low levels of DNA damage in individual cells. Exp Cell Res. 1988;175(1):184-91. [PubMed: 3345800].

12. Young Infants Clinical Signs Study G. Clinical signs that predict severe illness in children under age 2 months: a multicentre study. Lancet. 2008;371(9607):135-42. doi: 10.1016/S0140-6736(08)60106-3. [PubMed: 18191685].

13. Manucha V, Rusia U, Sikka M, Faridi MM, Madan N. Utility of haematological parameters and C-reactive protein in the detection of neonatal sepsis. J Paediatr Child Health. 2002;38(5):459-64. [PubMed: 12354261].

14. Winn WC, Koneman EW. Koneman's color atlas and textbook of diagnostic microbiology. Lippincott williams \& wilkins; 2006.

15. Hu CT, O'Shaughnessy KM. Glycerol-enhanced mini-polyacrylamide gel electrophoresis for the separation of differentially expressed DNA fragments in cDNA representational difference analysis. Electrophoresis. 2001;22(6):1063-8. doi: 10.1002/1522-2683()22:6<1063::AIDELPS1063>3.0.CO;2-S. [PubMed: 11358126].

16. Kermorvant-Duchemin E, Laborie S, Rabilloud M, Lapillonne A, Claris O. Outcome and prognostic factors in neonates with septic shock. Pediatr Crit Care Med. 2008;9(2):186-91. doi: 10.1097/PCC.ob013e31816689a8. [PubMed: 18477932].

17. Stoll BJ. Infections of the Neonatal Infant. In: Kliegman RM, Behrman RE, Jenson HB, Stanton BF, editors. Nelson Textbook of Pediatrics. Elsevier; 2008. pp. 794-811.

18. Hornik CP, Fort P, Clark RH, Watt K, Benjamin DJ, Smith PB, et al. Early and late onset sepsis in very-low-birth-weight infants from a large group of neonatal intensive care units. Early Hum Dev. 2012;88 Suppl 2:S69-74. doi: 10.1016/S0378-3782(12)70019-1. [PubMed: 22633519].
19. Strunk T, Currie A, Richmond P, Simmer K, Burgner D. Innate immunity in human newborn infants: prematurity means more than immaturity. J Matern Fetal Neonatal Med. 2011;24(1):25-31. doi 10.3109/14767058.2010.482605. [PubMed: 20569168].

20. El Kebir D, Filep JG. Role of neutrophil apoptosis in the resolution of inflammation. ScientificWorldJournal. 2010;10:1731-48. doi: 10.1100/tsw.2010.169. [PubMed: 20842319].

21. Guida JD, Kunig AM, Leef KH, McKenzie SE, Paul DA. Platelet count and sepsis in very low birth weight neonates: is there an organismspecific response?. Pediatrics. 2003;111(6 Pt 1):1411-5. [PubMed: 12777561].

22. Priyadharshini NA, Parkash C. Assessment of DNA damage in term neonates with sepsis by comet assay. Curr Pediatr Res. 2014;18(1).

23. Carvalho NC, de Souza RL, Dal-Pizzol F, de Andrade VM. Comet assay in neonatal sepsis. Indian J Pediatr. 2010;77(8):875-7. doi: 10.1007/s12098010-0127-9. [PubMed: 20721705].

24. Delanghe JR, Speeckaert MM. Translational research and biomarkers in neonatal sepsis. Clin Chim Acta. 2015;451(Pt A):46-64. doi: 10.1016/j.cca.2015.01.031. [PubMed: 25661089].

25. Meem M, Modak JK, Mortuza R, Morshed M, Islam MS, Saha SK Biomarkers for diagnosis of neonatal infections: A systematic analysis of their potential as a point-of-care diagnostics. J Glob Health. 2011;1(2):201-9. [PubMed: 23198119].

26. Garcia-Romo GS, Caielli S, Vega B, Connolly J, Allantaz F, Xu Z, et al. Netting neutrophils are major inducers of type I IFN production in pediatric systemic lupus erythematosus. Sci Transl Med. 2011;3(73):73ra20. doi:10.1126/scitranslmed.3001201. [PubMed: 21389264].

27. Yang KD, Chen MZ, Teng RJ, Yang MY, Liu HC, Chen RF, et al. A model to study antioxidant regulation of endotoxemia-modulated neonatal granulopoiesis and granulocyte apoptosis. Pediatr Res. 2000;48(6):829-34. doi: 10.1203/00006450-200012000-00021. [PubMed: 11102554].

28. Scheel-Toellner D, Wang KQ, Webb PR, Wong SH, Craddock R, Assi LK, et al. Early events in spontaneous neutrophil apoptosis. Biochem Soc Trans. 2004;32(Pt3):461-4. doi: 10.1042/BST0320461. [PubMed: 15157160].

29. Srinivasan L, Kirpalani H, Cotten CM. Elucidating the role of genomics in neonatal sepsis. Semin Perinatol. 2015;39(8):611-6. doi: 10.1053/j.semperi.2015.09.008. [PubMed: 26476786].

30. Paunel-Gorgulu A, Kirichevska T, Logters T, Windolf J, Flohe S Molecular mechanisms underlying delayed apoptosis in neutrophils from multiple trauma patients with and without sepsis. Mol Med. 2012;18:325-35. doi: 10.2119/molmed.2011.00380. [PubMed: 22231730].

31. Altrichter J, Sauer M, Kaftan K, Birken T, Gloger D, Gloger M, et al. Extracorporeal cell therapy of septic shock patients with donor granulocytes: a pilot study. Crit Care. 2011;15(2):R82. doi: 10.1186/cc10076. [PubMed: 21371308].

32. Payne CM, Glasser L, Tischler ME, Wyckoff D, Cromey D, Fiederlein R, et al. Programmed cell death of the normal human neutrophil: an in vitro model of senescence. Microsc Res Tech. 1994;28(4):327-44. doi: 10.1002/jemt.1070280408. [PubMed: 7919520]. 